\title{
The role of teachers in governing communities
}

\author{
Alex Sawaki and Marthin Senandi
}

Marthin Senandi: As civil servants who went to the field posts, there were a number of things we had to learn. ${ }^{1}$ Despite the many theories we had learned, we could not necessarily apply them yet in the villages. When we arrived, we first of all tried to find out about local circumstances through the teachers, whether they were schoolteachers or religious teachers. Although it was the village heads who served as our spearheads in the villages, because we were their superiors, they never wanted to tell us about the true situation.

Because of that, we could find out about the situation of the communities there better through the teachers, whether they were religious teachers or schoolteachers. Religious life was strong in the communities in the villages. They trusted the teachers more; therefore we could implement governance there. Only once we had learned their customs could we properly implement governance there. Because if we did not master the adat of the place, it would be difficult for us to expedite our jobs. The existing traditions could become barriers.

When visiting the villages, we always slept in the teachers' houses, and gathered data on the community from them. If there was a minister there, we would stay at his house. They openly told us about the situation of the community. And after we got well acquainted with the situation of the villagers, we endeavoured to do useful things for them. It was best to study their language, even though we used Indonesian (then known as Malay) as our working language. We tried to master a bit of their language.

\footnotetext{
Both Sawaki, who was a minister and schoolteacher, and Senandi, who was an administrator, took part in the interview for this chapter. In his introduction Senandi explains the important role of teachers in the everyday practice of governing communities. Then Sawaki continues from his own perspective and experience.
} 
Yes. We started from there. When we got involved with the community, as we chatted with them, we might be able to express greetings or say 'bon appétit' to them in their own language. We knew that if we mastered the people's language, we could govern them. Because theory alone was not enough to let us govern people. It was difficult to apply the scientific theories and languages we had learned through our education to the villages. Yes, we had the help of the teachers regarding the intricacies of local social conditions. In this way we could implement a system of governance whose smoothness would be assured.

In the villages we made great use of the teachers in performing our duties as civil servants. So, in the lectures or meetings we held with the communities, we also brought the teachers into our midst. We gave the teachers opportunities to speak, so that our intentions could be understandable to the people. Because if we alone spoke, they might perceive us as strangers, or they would not show up because they were afraid of government administrators. They would rather listen to the teacher; since he lived with them in the village every day, they would believe what he said. We had to involve them because they played an important role in the villages. If we had to do it without them, we would be totally blind to the conditions in the community.

Alex Sawaki: The teachers really knew a lot about the customs and other local knowledge of the communities. Such as issues related to marriage. Each area had its own adat and practices regarding marriage. Generally, marriages were performed in nearly the same way across a certain area, but the teacher would know more specifically how it was carried out in the village where he worked. In an adat marriage between a man and a woman, the man had to first ask the woman's parents for her hand in marriage. And the whole process was designed to follow adat ways, to ensure that no problems arose between the two sides. Thus, the marriage would proceed well without any disputes between the two, so the government would not need to intervene. When incidents happened in a given village, the teacher would give advice based on religion, in order to change ways of life that were contrary to Christianity.

Another example of the role of the teachers was when there was work that called for mutual cooperation to build something. A plan would be submitted by the government, in this case, by the civil servant, instructing the villages through the village heads to implement some kind of work, for example, to clean up the village, or construct a house. 
After the village chief received the instructions, he had no choice but to contact the teacher in his village. This was because for the villagers, the teacher was the one who could clarify any gaps in understanding the community had. The teacher helped the village head to explain any order that came from a government official. And the communities there had more respect for the teacher because they knew that the teacher was a servant of God. He told the truth; he preached about the road to salvation for humankind according to the Bible - the word of God. $\mathrm{He}$ preached the gospel of human salvation. So the teacher was respected, and his words were carefully heeded.

Yet another example of this was the issue of how the teachers based in the midst of the community lived, in economic terms. Formerly, the teachers' livelihoods were almost entirely taken care of by the communities. It was the communities that maintained the teachers and gave them food. When people came home from their gardens with produce, they shared it equally by giving some to the teacher. This meant that the teacher did not go anywhere, but stayed in the place all the time.

If you compare the schools located in remote areas with those in communities in the cities, or in coastal areas that are already fairly advanced, in these places more crowded with people who already understand things, the life of a teacher is considered normal, just like anyone else's. Life in the villages in the past was closed off from the outside world. People lived in isolation in their own village neighbourhoods and areas, and did not know much about the situation outside. In that period, cooperation between teachers and government administrators was essential.

That cooperation was crucial to revitalize the lives of the communities and people found in the area governed by an administrator. The cooperation was necessary and good. In those days, cooperation was excellent, whereas these days, it almost never happens anymore. Yet cooperation is still highly necessary. In the cities, people generally do not distinguish, respect, or heed either the teacher or the government administrator. Thus, each works on his or her own, so that the change and progress they hope for cannot possibly be quickly achieved.

I think that the foundation is that cooperation. Then, mutual human respect. If human beings do not respect one another according to the fundamentals of religious faith, then human beings will never recognize one another. 
The principle of love between one person and another must exist. Although a person may be someone other than your own brother or your own tribe, the principle of love can embrace all the human beings in the same area, so that disputes or riots can be overcome through their respective religious convictions. If you call out for human well-being and respect, but it is not grounded in the law of religion, it will be in vain. Ah, that is an effort that needs to be addressed by government and religion together, to ensure the welfare of the people of the region under their legal authority.

With the existence of cooperation between government and religion, a wonderful purpose for humans can be achieved, that is, their well being. If the economy is good, but the working relations between human beings is not normal, in the sense that they are not purely based on the law of religion and the law of government, or legislation, then the aims they commonly desire will not be realized. 